\title{
ORTHOEPIA OF SUPRASEGMENTAL PROPERTIES AS A PREREQUISITE FOR COMMUNICATION
} SKILLS

\section{ORTOEPIA SUPRASEGMENTÁLNYCH VLASTNOSTÍ AKO PREDPOKLAD KOMUNIKAČNÝCH ZRUČNOSTÍ}

\begin{abstract}
The main objective of this study is to bring experience from the development of suprasegmental phenomena to pupils learning to read, fluently speaking with the emphasis on raising the language level and cultivating the auditory form of correct speaking and literary Slovak.

\section{RESUME}

Hlavným cielom tejto štúdie je sprostredkovat skúsenosti z rozvíjania suprasegmentálnych javov u žiakov, ktorí sa učia čítat', plynule rozprávat’s akcentom na zvyšovanie jazykovej úrovne a kultivovanie auditívnej podoby správneho hovorenia a spisovnej slovenčiny.
\end{abstract}

Keywords: ortoepia, suprasegments, teacher, pupil, language

Klúčové slová: ortoepia, suprasegmenty, učitel, žiak, jazyk

\section{ÚVOD}

Ortoepia je doslovne správne hovorenie. Často sa definuje ako náuka o spisovnej výslovnosti. Král (1983, s. 16) definuje ortoepia nasledovne „Ortoepia je náuka o zvukových normách spisovného jazyka. Je to súhrn 
pravidiel správneho tvorenia (generovania) a správneho znenia zvukových prejavov v spisovnom jazyku z hladiska ich zvukových vlastností”.

Suprasegmenty sa viažu na vyššiu jednotku ako je hláska. Napr. na slabiku, slovo, vetný úsek a vetu. Vnímajú sa už v rámci slabiky ako základné jednotky v súvislej reči. Sú velmi variabilné. Poskytujú nám informácie o hovoriacom.

Keby boli hlásky vedla seba mechanicky nakopené, naša reč by znela monotónne, počúvajúci by ju vnímal s vel'kou námahou, bola by tažko zrozumitelná. Človek preto využíva svoju schopnost' predlžovat', zosilňovat' a zvyšovat' (znižovat') hlas, menit' jeho farbu, zrýchlovat' (spomal'ovat') tempo reči. Uvedené schopnosti človeka sa prejavujú na fonickom rade a jeho jednotkách ako tzv. prozodické vlastnosti reči (Baláž, 2000, s. 55).

Alexandra Záborská (2009, s. 20), ktorá pripravuje poslucháčov herectva na ich povolanie kladie dôraz aj na fonetické paralingvistické prostriedky. Sú to napríklad sila, výška a farba hlasu, tempo a plynulost̉ reči, rytmus a podoby melodických intervalov a spôsoby frázovania, ako aj kvalita artikulácie. V prejave sa najčastejšie vyskytuje komplex týchto prvkov a absencia hociktorého $\mathrm{z}$ nich môže značne deformovat' obsah výpovede. Kvalita artikulácie a odklony od ortoepickej normy sa tiež môžu kvalifikovat’ ako paralingvistický prvok v reči.

Všetky prostriedky, ktoré ovplyvňujú zvukovú podobu hovoreného sa navzájom dopĺnajú, zastupujú a striedajú sa ako najlepší bratia a lebo spolupracovníci. Najradšej sú však spolu: tam, kde je výrazná melódia, je výrazný prízvuk a niekde nablízku aj prestávka. Často pri zmene melódie, dôrazu a na mieste prestávky je aj zmena tempa alebo rytmu (Mistrík, 1999, s. 162).

Suprasegmentálne javy sa označujú ako prozodické vlastnosti reči. Suprasegmentálne javy sú dané istou moduláciou (úpravou) artikulačného prúdu, hlasu. Vnímajú sa v rámci slabiky, ktorá je základnou jednotkou súvislej reči. Artikulačný prúd (hlas) možno modulovat trojako: časovo, silovo, tónovo.

\section{1. Časová modulácia reči}

Z hladiska časovej modulácie reči vznikajú tieto suprasegmentálne javy: kvantita, pauza, tempo a rytmus. 


\section{Kvantita}

Kvantita, čiže dĺžka je nositelom slabičnosti.

Časovou, silovou a tónovou moduláciou artikulačného prúdu hlasu vznikajú suprasegmentálne javy, ktoré sa na základné (segmentálne) jednotky navrstvujú alebo sa medzi ne vsúvajú (pauza). Kvantita ako jediný zo všetkých suprasegmentálnych javov má práve protiklad dlhých a krátkych samohlások a slabičného r,l, schopnost’ rozlišovat’ významy slov a tvarov. Názory na pomer krátkych a dlhých nositelov slabičnosti sa v slovenskej jazykovede postupne menili. Podla Paulinyho (1979, s. 141) „Slovenská dlhá samohláska je skutočne dlhá, je totiž dva razy dlhšia ako krátka samohláska. Rovnako tak dvojnásobok dľžky krátkej samohlásky majú diftongy a dvojnásobne dlhé sú aj dlhé slabičné spoluhlásky ŕ, l..."Neskôr Sabol experimentálne ukázal, že ich pomer, že ich pomer je približne 1:1,66. V závislosti od tempa reči j jednotlivých štýloch je tento pomer 1:1,34 (hovorový štýl), 1:1,66 (publicistický štýl) a 1:1,64 (umelecký štýl). Realizáciu kvantity ovplyvňuje však, nielen jazykový štýl, ale aj poradie slabiky v slove, druh vokálu či hláskové okolie (Daržágín a kol., 2005, p. 170). Findra (2005, p. 124) podla Autority Slovenskej gramatiky Paulinyho, Ružičku a Štolca píše o mórovom charaktere slovenčiny. Výslovnostný pomer krátkeho a dlhého nositela slabičnosti sa určil 1:2. Dlhá slabika predstavuje súčet trvania dvoch krátkych slabík čiže dvoch mór.

Dĺžka je nielen vlastnostou samohlások, t.j. fonologickou vlastnostou, ale aj vlastnostou suprasegmentálnou, lebo sa prejavuje na slabike. Ako rytmický činitel' sa dížka prejavuje v striedaní dlhých a krátkych slabík (Baláž, 2000, s. 55).

Kvantitu treba chápat ako súčast' celého komplexu d’alších zvukových javov. Nemožno ju vnímat a trénovat izolovane - kvantita totiž súvisí s dostatočným dychovým napätím pri hovorení, súvisí s artikulačnou a zvukovou vyváženostou a s vnímaním reči ako súvislého toku zvuku (Čertíková, 2005, s. 169). Podla Králika (2005, s. 63) „slovenčina patrí k jazykom, v ktorých dĺžka samohlásky rozhoduje o význame slova - je dištinktívna. Rozdiely v kvantite sa v niektorých slovách využili na rozlíšenie významov slov“.

Historické parametre kvantity sa odvíjajú od praslovanského dedičstva vztahov medzi fonémami v štruktúre slabiky a morfémy (Sabol, 2005, s. 10). 
Výslovnost'krátkych a dlhých vokálovjevšak dôležitá nielenzvýznamového, ale aj z ortofonického a ortoepického hladiska. Hoci je samotný subsystém slovenských krátkych a dlhých samohlások vo svojej podstate jednoduchý, lebo z hladiska spisovnej výslovnosti nepredstavuje osobitné problémy, predsa práve nedodržiavanie kvantity vokálov patrí medzi najčastejšie chyby $\mathrm{v}$ hovorených prejavoch. Všeobecne platí, že tendencia predlžovat krátke vokály je typická najmä pre západoslovenskú oblast', kým skracovanie dlhých vokálov je zasa charakteristické pre Východoslovákov (Navrátil, 2005, s. 153). Milan Majtán (2005, s. 145-147) hovorí o tzv. posunutej dľžke v južnostredoslovenských nárečiach. Účinkom rytmického krátenia sa posúva dížka z poslednej slabiky na predposlednú alebo vplyvom východoslovenský prízvuk sa prehodnotil na dížku na predposlednej slabike v zhode so zákonom rytmického krátenia. Ján Findra (2005, s. 125) upozorňuje, že komplexne „v ústnych jazykových prejavoch sa výrazne skracuje dĺžka trvania artikulácie dlhých nositelov slabičnosti, ba že v mnohých prípadoch sa protiklad dlhej a krátkej slabiky stiera“.

Využívanie kvantity je v spisovnej slovenčine regulované tzv. pravidlom o rytmickom krátení, rytmickým zákonom. Podla neho dve dlhé slabiky nemôžu nasledovat' $\mathrm{v}$ jednom slove bezprostredne za sebou. Ak by taký prípad pri ohýbaní alebo pri tvorení slov nastal, druhá slabika sa kráti. Znamená to, že predchádzajúca dlhá slabikotvorná fonéma pôsobí na nasledujúceho nositela slabičnosti $\mathrm{v}$ rámci slova a vynucuje si skrátenie jeho systémovej dĺžky. Rytmické krátenie, čiže skracovanie systémovo dlhej slabiky po dlhej slabike, odohráva sa jedine v rámci slova, za hranice slov neprechádza. Lenže neutralizácia kvantity, pravidlo o rytmickom krátení neplatí dôsledne a bezvýnimočne, ale narúša sa v niektorých prípadoch pod tlakom iných rovín jazyka. Nie každá dlhá slabika sa po predchádzajúcej dlhej slabike skracuje. V početných prípadoch sa skracovanie neuskutočňuje. Takéto prípady sa tradične označujú ako výnimky z rytmického krátenia. Za výnimky sa považujú len tie prípady, pri ktorých skutočne ide o neskrátenú dlhú slabiku stojacu po inej dlhej slabike. Podla pravidiel slovenského pravopisu jestvuje v súčasnej spisovnej slovenčine 12 výnimiek z pravidla o rytmickom krátení, ktoré sa dajú odôvodnit zákonitostami obmedzujúcimi platnost' tohto zvukového pravidla jednak z tvarotvorných dôvodov, jednak 
zo slovotvorných dôvodov, pričom ide o výnimky, ktoré vznikajú pri procese tvorenia nových slov deriváciou alebo kompozíciou (Navrátil, 2005, p. 152).

Už Ludovít Štúr pri kodifikácii spisovnej slovenčiny prevzal do nového spisovného jazyka aj rytmické krátenie druhej slabiky v slove ako špecifickú črtu stredoslovenských nárečí. Vychádzal z vlastného poznania jazykových zákonitostí i z postoja svojich stredoslovenských spolupracovníkov. O tom, že v ich vedomí bolo rytmické krátenie druhej dlhej slabiky pevným prvkom prozodického systému, máme dodnes dôkazy v štúrovskej poézii (Ferenčíková, 2005, s. 130). Fungovanie kvantity v spisovnej slovenčine a jej regulovanie osobitným typom neutralizácie tzv. rytmickým zákonom, predstavuje, ako sa všeobecne uznáva v domácej i zahraničnej lingvistike, jednu z najsvojráznejších zvukových čŕt spisovnej slovenčiny (Ondrejovič, 2005, s. 107). Považaj (2005, p. 95) píše, že „pravidlo o rytmickom krátení sa neuplatňuje dôsledne a už od Štúrových čias sa počet výnimiek z tohto pravidla postupne rozširoval.

Reguláciou kvantity v slove alebo v tvare rozumieme distribúciu slovnej kvantity alebo jej prehodnocovanie v súhlase s požiadavkami zákona o slovnej kvantite $\mathrm{v}$ slovenčine. Výsledkom regulácie kvantity býva jej obmedzenie v slove, prípadne v tvare alebo v celej paradigme (Kačala, 2005, p. 45).

\section{Pauza}

Pauza, čiže prestávka, je prerušenie hlasového a artikulačného prúdu reči. Počas prestávky neznie rečový zvuk. Prestávkou sa neoddelujú jednotlivé slová, ale zvyčajne väčšie celky.

Mistrík (1999, p. 116) vo svojom obšírnom diele venovanom jazyku a reči píše: „Ked’ čítame bežný text, zdá sa nám, ako keby bol rozsekaný na vety s rovnako ostrými hranicami. Zdá sa nám, ako keby vety boli úseky podobné slovám. Zatial' však hranice medzi vetami nie sú také ostré a jednoznačné ako medzi slovami“. Ďalej Mistrík (1999, s. 161) tvrdí, že súvislý prejav sa prerušuje $\mathrm{z}$ objektívnych príčin. Niekedy ho preruší neočakávaný zásah zvonku (mechanické prerušenie), niekedy je príčina prerušenia fyziologická, napríklad na dýchanie, často sa prejav prerušuje preto, aby sa signalizovalo gramatické členenie vety alebo textu, no často sa preruší z nejakej vnútornej príčiny hovoriaceho - chce vyjadrit cit, náladu, 
pátos, chce niečo osobitne zdôraznit alebo nedopovedat', zamlčat'. Každá veta je členená na také úseky, ktoré pripúštajú alebo žiadajú prestávku kvôli zrozumitelnosti reči. Hovoriaci si takéto gramatické pauzy ani neuvedomuje, lebo to preňho znamená to, čo pri písaní napísanie, čiarky, bodky, a pod. ktoré si vyžaduje zrozumitel'nost̉ textu.

Jednotlivé časti vety oddelujeme od seba tak, že prerušíme artikuláciu. Takéto prerušenie artikulácie sa nazýva prestávka alebo pauza. Prestávku vo vete nemôžeme urobit’ na hociktorom mieste. Pri kladení prestávky musíme rešpektovat významovú a gramatickú stavbu vety. Vo vete sú miesta, kde nesmieme prestávku urobit', lebo nám to nedovoluje význam a naopak, kde prestávku môžeme, alebo musíme urobit'. Pre správne kladenie páuz je dôležité hospodárne narábat’ s artikulačným prúdom. To znamená, aby sme z fyziologických príčin nemuseli urobit pauzu tam, kde to významová a gramatická stavba vety nedovoluje. Aj napriek tomu je v reči viac prestávok, než to naznačujú $\mathrm{v}$ písanom jazykovom prejave interpunkčné znamienka. Pauzy sa robia aj na takých miestach vo vete, kde sa čiarka nepíše (Baláž, 2000, s. 63-64). Mistrík (1999, s. 161) pomenúva aj další typ prestávky v reči, pri interpretácii umeleckých textov. Jedná sa o umeleckú prestávku (pauzu) v texte. Umelecká prestávka je dramaticky silný prvok, pretože je to neočakávané odmlčanie, neočakávaná dľžka alebo úmyselné ignorovanie prestávky. Umelecká prestávka sa môže uplatnit iba na tých miestach, kde nedôjde k nedorozumeniu, kde je jasná gramatika textu. Dobrá umelecká prestávka musí byt citelná d’aleko $\mathrm{v}$ texte i ponad text. $\mathrm{V}$ umeleckom prejave platí licencia poetica, to znamená dovolenie porušit jazykový zákon v záujme estetickosti textu.

Baláž (2000, s. 64) člení prestávky na:

1. Nekončiace pauzy - melódia vetného úseku pred nimi naznačuje, že po pauze bude hovoriaci vo výpovedi pokračovat.

2. Končiace pauzy - melódiou na konci vety hovoriaci naznačuje, že výpoved' sa skončila.

Všeobecne pauza môže byt:

1. Fyziologická - vzniká pre potreby dychu.

2. Významová - pomáha členit’ dlhšiu výpoved', aby bola zrozumitelná. 
3. Umelecká - robí ju rečník, recitátor. Používa sa zámerne pred výpoved’ou, ktorú chceme zvýraznit.

4. Pauza z váhania - nie je zámerná, počas nej sa hladá slovo, výraz. Nie je chybou, robia ju aj skúsení rečníci. Nemá sa vypĺn̆at’ „pazvukmi“: hm, nó, á....

Podla Bekéniovej (2010, s. 36) si žiaci musia uvedomit', ako slúži pauza v bežnom živote, kedy ju spontánne a bez zvláštneho uvedomovania si používat’ v konaní, v reči. Trénujeme ju prostredníctvom situačnej rolovej hry.

\section{Tempo}

Tempo, čiže spád, je množstvo vyslovených slabík za istú časovú jednotku.

Ked’ pozeráme na tlačený text v knihách, zdá sa nám, že všetko je v ňom fantasticky rovnomerné. To sa nám predvádzajú pravidelné riadky, rovnaké písmená, zhodné medzery. Ked’ sledujeme litery v riadkoch len ako mŕtve znaky, vybavuje sa nám pochod písmen, idúcich za sebou rovnomerným krokom. Ale ked' odpútame pozornost' od formy a sústredíme sa na obsah, v tom momente sa nám usporiadaná plocha premení na pole, „kmásané“ vetrom a „zmývané“ daždom. A podobne sa nám „rozsypú“ písmená a slová $\mathrm{v}$ riadkoch. Odrazu cítime, akoby boli naukladané husto, inde neobyčajne riedko. Tempo písmen a tempo riadkov sa nemení, ale tempo textu sa stále mení - niekedy zvol’na, inokedy až vel’mi prudko (Mistrík, 1999, s. 83).

Rýchlost’ artikulácie hlások vo všetkých častiach jazykového prejavu nie je rovnaká. Napr. rečník pri slávnostnom prejave hovorí rýchlostou asi 60-80 slov za minútu. Hovoriaci ju môže menit. Niektoré časti jazykového prejavu môže povedat rýchlejšie, iné pomaly. Zmeny v rýchlosti jazykového prejavu nazývame tempom reči.

Tempo môže byt:

1. Vecné - závisí od obsahu jazykového prejavu. Dôležité veci hovoríme obyčajne pomaly, menej dôležité.

2. Osobné - odvíja sa od individuálnych zvyklostí hovoriaceho. Reč ludí s pokojnou povahou býva pomalšia, temperamentní ludia hovoria väčšinou rýchlejšie. 
Tempo reči nemá byt’ nikdy také rýchle, aby hovoriaci nemohol náležite artikulovat všetky hlásky. Tempo reči nemožno presne určit. Preto sa v písanom prejave nijako nevyznačuje (Baláž, 2000, s. 63).

Tempo čiže rýchlost' je fyzická vlastnost', ale na základe rýchlosti prejavu sa dá vyjadrit stupeň jeho dôležitosti a jeho hodnota. Tempo sa v texte, ale i vo vete môže striedat: pomalé tempo signalizuje, že ide o dôležitú čast', ktorá sa práve spomalením podčiarkuje. Rýchle tempo je znak menšej dôležitosti textu alebo aj znak dramatickosti, citového zanietenia. Istú štylistickú hodnotu neoznačuje len tempo, ale najmä miesta, na ktorých sa tempo mení - z vysokého na mierne, zdržanlivé, alebo naopak. Odborne sa takéto miesta striedania tempa nazývajú agogikou (Mistrík, 1999, s. 162).

Mislovičová (2005, s. 158) poukazuje na to, že v súčasnosti sú v hovorených prejavoch v médiách aktuálne nedostatky súvisiace so vztahom tempo reči a nedodržiavanie kvantity v slovách a tvaroch. Tento vztah totiž funguje ako spojené nádoby: moderátor skracuje dlhé slabiky a tým zrýchluje tempo reči alebo naopak, rýchle tempo reči je príčinou nedodržiavania príslušných dížok a polavenia $\mathrm{v}$ artikulácii. Niektorí profesionálni používatelia jazyka akoby zabudli, že v slovenčine existujú dlhé slabiky, menia tak rytmus slovenskej vety. Skracovanie dlhých samohlások, resp. slabík je pritom vážnou ortoepickou chybou.

Čertíková (2005, s. 165) tvrdí, že adepti na prácu v slovenskom rozhlase venujú ovela menej pozornosti výslovnostnej stránke prejavu a skôr sa usilujú o dynamiku, ktorú si neraz zamieňajú za rýchlost'. Ich prejav poznačuje svojská vetná melodika zvukovo vyzdvihujúca prísudkovú čast’ vety na úkor predmetovej. Ich prejav je potom zvukovo a melodicky značne nevyvážený.

Rýchle rečové tempo ovplyvňuje vel’mi výrazne aj prirodzené hranice slovných taktov, ktoré poslucháč vníma ako základné signály na porozumenie významu. V rytmickom členení sa stáva základným prvkom slabika. $\mathrm{V}$ rýchlom tempe sa tak reč rytmicky realizuje ako rýchly sled za sebou letiacich slabík bez taktového ohraničovania. Intonačné vrcholy sa presúvajú zo začiatkov slovných taktov skôr na ich konce. Zaujímavé je, že kým tento štýl je pre strednú a staršiu generáciu absolútne neprijatelný, mladá generácia ho zväčša vníma ako dynamický a atraktívny (Čertíková, 2005, s. 166). 


\section{RYTMUS}

Rytmus vzniká striedaním prízvučných a neprízvučných slabík. Je to rytmické vlnenie od slabiky $\mathrm{k}$ taktu.

Slovo rytmus má široký význam. Stretávame sa s ním všade tam, kde sa javy s istou zákonitostou striedajú. Rytmus sám osebe nemôže existovat: potrebuje prostriedky, na ktorých sa môže realizovat'. Všetky výrazové prostriedky v komunikácii sú schopné vytvárat rytmus, ale iba na pôde kontextu. Rytmus je teda kontextový jav (Záborská, 2009, s. 20).

Rytmus sa niekedy mylne zamieňa s tempom prejavu. Rytmus však vzniká tam, kde sa niečo strieda, opakuje. Ked’ má rytmus malé alebo časovo krátke časti (stopy), uvedomujeme si ho skôr ako taký, ktorý má dlhé opakovacie stopy alebo v ktorom sa strieda široká paleta častí, stôp. Rytmus sa v jazykovom prejave využíva ako estetický prvok. Využíva sa rovnako jeho opakovanie, ako aj narúšanie a zmeny (Mistrík, 1999, s. 162).

\section{Silová modulácia reči}

Prostriedkami silovej modulácie reči sú: intenzita, akcent, dôraz, emfáza.

\section{INTENZITA}

Intenzita je sila hlasu. Celkový silový register závisí od vonkajšej situácie prejavu. V auditívnej podobe jazyka môžeme využit škálu intenzity, ktorá sa používa v dynamike hudby: pp, p, mf, f, ff. Tichý prejav prijímatela unavuje, hlasný prejav ho môže dráždit. Takéto prejavy môžu končit’ stratou záujmu o obsah.

\section{AKCENT}

Nositelom akcentu, čiže slovného prízvuku je slabika.

Rovnako ako v piesni existujú tažké a lahké doby, to jest dôrazné a nedôrazné slabiky, ktoré tvoria stopy, tak existujú tažké a lahké doby aj v ústnom prejave.

Naša náuka o slovnom prízvuku hovorí, že prízvuk pripadá pravidelne na prvú slabiku, ale o slovách vnútri taktu treba ho štylizovat' inakšie. V štvorslabičnom takte prízvučná je prvá a predposledná slabika... Z d’alej uvedených úvah u Krčméryho vyplynulo, že „v normálnom hovorenom takte hlavný prízvuk pripadá na prvú, vedlajší na predposlednú slabiku“ (Krčméry, 1932, s. 11). Aj Mistrík (1999, s. 185) hovorí, že „v slovenčine sú prízvučné prvé slabiky v slovách". 
Pod pojem akcent čiže prízvuk zahŕňa jazykoveda rozdiely v sile a výške hlasu. Prízvuk má teda dvojakú stránku: silovú (dynamickú) a tónovú (melodickú). Podla toho, ktorá stránka sa uplatňuje vo väčšej miere, rozoznávame vo všeobecnosti dvojaký prízvuk.

\section{a) dynamický,}

Pri dynamickom prízvuku sa prízvučná slabika od neprízvučnej odlišuje predovšetkým väčšou intenzitou hlasu. Rozdiely vo výške tónu, na ktorom slabiku vyslovíme, sú menej dôležité.

b) melodický.

Pri melodickom prízvuku sa prízvučná slabika od neprízvučnej odlišuje výškou tónu, na ktorom ju vyslovujeme. Sila hlasu je v takomto prípade druhotná.

Dynamický prízvuk má dva stupne:

1) hlavný prízvuk,

2) vedlajší prízvuk.

Hlavný prízvuk je najsilnejší prízvuk v slove (v takte). Vedlajší prízvuk je slabší ako hlavný. Nositelom prízvuku je slabika. Slabiky, ktoré majú hlavný alebo vedlajší prízvuk sa nazývajú prízvučnými. Ostatné slabiky v slove alebo takte sú neprízvučné. V slovenčine nemôžu za sebou nasledovat v takte dve prízvučné slabiky. Po prízvučnej slabike môže nasledovat' jedna alebo dve neprízvučné slabiky.

Dvojslabičné a trojslabičné slová majú hlavný prízvuk na prvej slabike. Vedlajší prízvuk nemajú. V štvorslabičných a pätslabičných slovách býva hlavný prízvuk na prvej slabike a vedlajší na predposlednej slabike. Vo viacslabičných slovách sa strieda prízvučná slabika s neprízvučnou. Jednoslabičné slová bývajú prízvučné i neprízvučné. Prízvuk jednoslabičného slova závisí od jeho polohy (Baláž, 2000, s. 56-57).

\section{Dôraz}

Dôraz tzv. vetný prízvuk sa prejavuje na slabike, ale uvedomuje sa ako vlastnost' slova alebo taktu. Je to zosilnenie hlasu pri výslovnosti významovo 
najdôležitejšieho slova vetného úseku. Dôraz nie je pevne stanovený, pomocou neho sa môže menit’ zmysel výpovede.

Vo vete nikdy nie sú všetky slová rovnako dôležité. Aj ked’ sa hovoriaci vyjadruje vo vetách, každá z nich má jadro, kvôli ktorému sa vyslovila. Vo vete môžeme zdôraznit’ vždy iné slovo. Závisí to od potreby hovoriaceho alebo počúvajúceho, ktorá čast’ vety je jadrom. Vo väčšine jazykov sa na jadro vo vete upozorní silnejším dôrazom, akcentom, zosilneným hlasom. Silový dôraz o ktorom sme hovorili, sa nazýva logickým. Okrem logického existuje aj citový dôraz, ktorý je vedlajším, druhým dôrazom vo vete (Mistrík, 1999, s. 160).

Dôraz sa uplatňuje v rámci vety. Je to vynaloženie väčšej sily na najdôležitejšie slovo vo vete. Preto sa dôraz niekedy nazýva aj vetný prízvuk. Úlohou dôrazu je vyjadrit’ stanovisko hovoriaceho k vlastnému jazykovému prejavu. V pokojnej reči býva dôraz na konci vety. Vo vzrušenej reči býva dôraz na začiatku vety. Hovoriaci môže aj na základe situácie menit miesto dôrazu vo vete. Tak dostáva tá istá veta rozličné významové odtienky (Baláž, 2000, s. 59).

V grafickom prejave sa dôraz nevyznačuje. V mimoriadnych prípadoch sa dôrazové slovo podčiarkne alebo sa vyznačí iným typom písma (Baláž, 2000, s. 60).

\section{EmFÁzA}

Emfáza je citový dôraz, ktorý sa vyznačuje nápadným melodickým pohybom. Obyčajne sa vyjadruje predľžením samohlásky. Je výrazom extrémneho citového postoja hovoriaceho k vypovedanému.

\section{Tónová modulácia reči}

Nástrojmi tónovej modulácie reči hlasový register a melódia.

\section{HLasový Register}

Hlasový register vzniká nasadením hlasu do istej výšky. Uvedomuje sa ako zmena výšky hlasu po sebe nasledujúcich nositelov slabičnosti.

Pri fonácii by sme mali používat svoju individuálnu strednú polohu hlasu, tzv. miešaný tón, čo nám umožní s hlasom plasticky narábat. Potrebné je dbat' o to, aby bol hlas dostatočne rozrezonovaný, kultivovat, jeho farbu hlasu zapájaním rezonancie (Čertíková, 2005, s. 167). 


\section{Melódia VeTy}

Podla Krála (1983, s. 172) je melódia vety „pohyb, zmena a vlnenie tónovej zložky reči. Je to zmena výšky hlasu pri reči čiže časový priebeh výšky hlasu. Melódia vzniká činnostou hlasiviek. “Je vyjadrená kĺzavým spôsobom.

Melódiou vo vete v slovenskom jazyku sa zaoberal už Štefan Krčméry, ked' napísal: „Naše hovorenie netečie rovnakým tónom. Je rytmické a melodické. Cítit’ v ňom vlnenie hlások mocnejšie a slabšie vyslovovaných (prízvuk) a cítit vlnenie hlások vyššie a nižšie intonovaných (melódia). Ked’ načúvaš temperamentnému hovoru na slovenskom trhu alebo lúke, zaleje ta celá kaskáda melódií. Temer ani slova monotónneho. Slabika vystupuje nad slabiku, ako by si bežal prstami po klávesoch, a zas sa spúšta v bohatej rozmanitosti intervalov“ (Krčméry, 1932, s. 1).

Mistrík (1999, s. 159-160) prirovnáva melódiu reči piesni. Podobne ako má pieseň svoj nápev, tak má svojský „nápev“ aj živá reč. Nápev je vlnenie tónu, je to striedanie výšky. Odborne sa takéto vlnenie nazýva melódiou. Miesta, na ktorých sa mení smer tónu, sú klúčovými miestami vo vete a aj v texte. Melódia môže vo vete aj vyjadrovat city a nálady človeka. Čím je jazykový prejav pomalší, tým je jeho melódia viacej zvlnená, a čím je rýchlejší, tým je melódia stereotypnejšia. Pre význam vety nie je dôležitá absolútna výška hlasu, ale rozdiely medzi najvyšším a najnižším tónom (to sú melodické intervaly), prípadne častost' striedania výšky hlasu (to je frekvencia vlnenia).

Opytovacia veta vyjadruje, formuluje otázku. Pomocou opytovacej vety sa chceme dozvediet’ to, čo je neznáme, nejasné, nerozriešené. Zjednodušene: opytovacia veta je veta, ktorá má v písomnom prejave na konci otáznik a $\mathrm{v}$ ústnom prejave opytovaciu intonáciu. Opytovacie vety majú medzi ostatnými druhmi viet osobitné postavenie. Otázky sú v podstate dvojaké:

Dopĺňacie sú také otázky, ktorými sa žiada doplnit’ jednu „neznámu“, akoby „X“ v rovnici. V jazyku sa však v opytovacích vetách namiesto matematického x používajú opytovacie zámená, ktoré sa v slovenčine začínajú na k/č (kto, čo, kedy, kde, /pre/čo).

Zistovacie otázky sú otázky očakávajúce iba jednu z dvoch odpovedí - áno alebo nie, súhlasnú alebo zápornú odpoved' (Mistrík, 1999, s. 130).

V Knihe o detskej sa uvádza, že dospelý má používat’ otázky len vtedy, ak naozaj očakáva od dietata odpoved'. Nekladie otázky len preto, aby „nestála 
reč“. Treba sa vyvarovat’ otázkam, ktoré sa pýtajú na zjavné informácie, bombardujúcim otázkam, zle načasovaným otázkam, ked’ žiak sa venuje inej téme, častému používaniu otázok, na ktoré sa dá odpovedat áno/nie (Horňáková a kol., 2005, s. 30-31).

Melódia reči súvisí s myšlienkovým a citovým obsahom vety. Melodický priebeh vety je dôležitý najmä na konci vety a pred prestávkou vnútri vety. Melódiu vetného úseku, za ktorým nasleduje prestávka koniec vety, nazývame kadenciou. Kadencia má klesavý ráz. Zo začiatočnej vysokej polohy melódia dost' rovnomerne klesá až do relatívne najhlbšej polohy pred pauzou naznačujúcou koniec vety. Kadenciou hovoriaci naznačuje, že už nebude vo vete dalej pokračovat', že je veta ukončená (Baláž, 2000, s. 60). Podla Čertíkovej (2005, s. 168) sú v praxi časté začiatky viet a nových tematických celkov vedených intonačne zdola. Tento intonačný začiatok poslucháčovi nesignalizuje zmenu, nástup nového momentu v texte. Hovoriacemu vnucujú intonačne rovnú melódiu, ktorá sa tažko vníma a pôsobí nezaujato. Pri rovnej vetnej melódii sa stráca zretel’nosţ „bodky“ ako intonačného uzemnenia výpovede. Keď̌e sa už hlasom nedá íst’ nižšie, melodický pohyb končiacej kadencie býva nahrádzaný silou, „dotlačením“ bodky. Baláž (2000, s. 60) uvádza, že kadenciou končia oznamovacie, rozkazovacie, zvolacie a dopĺn̆acie opytovacie vety.

Melódia vetného úseku, za ktorým nasleduje prestávka naznačujúca koniec vety, sa nazýva polokadenciou. Pri polokadencii v pokojnej výpovedi melódia od začiatku vetného úseku klesá, ale na poslednom takte pred prestávkou sa zvýši a na tejto výške zostáva až do ostatnej slabiky taktu. Polokadenciou hovoriaci naznačuje, že výpoved' neskončil, že v nej bude ešte pokračovat. Polokadencie sa nachádzajú vnútri jednoduchých viet i súvetí pred prestávkou (čiarkou) (Baláž, 2000, p. 61).

Melódia vetného úseku neuspokojivo skončeného sa nazýva antikadenciou. Charakteristickým znakom antikadencie je vysoký tón, umiestnený na slove s dôrazom. Antikadencia sa podobá polokadencii, lebo obe vo všeobecnosti charakterizuje stúpavý ráz. No kým polokadencia naznačuje, že po pauze má vo výpovedi pokračovat ten istý podávatel', zatial antikadencia žiada odpoved' od prijímatela. Antikadenciu majú zistovacie opytovacie vety. Sú to vety, ktoré si žiadajú potvrdenie alebo popretie obsahu celej vety. Odpovedou na 
ne je áno, nie, prípadne celá kladná alebo záporná veta alebo jej čast'. Velmi zretel'ný stúpavý ráz s vysokým tónom na poslednej slabike majú zistovacie opytovacie vety s jednoslabičným alebo dvojslabičným koncovým taktom a s dôrazom na ostatnom slove (Baláž, 2000, s. 61-62).

\section{Zoznam bibliografických odkazov}

Bekéniová, L. (2010). Kultivovanie jazyka a reči detského recitátora, Bratislava: Metodicko-pedagogické centrum. ISBN 9788080523565.

Čertíková, H. (2005). Kvantita v Slovenskom rozhlase v súvislosti s ostatnými zvukovými zložkami, [in:] Kvantita v spisovnej slovenčine a v slovenských nárečiach, Bratislava: VEDA. ISBN 8022408581.

Daržágín, S., TRNKA, M., ŠTEFÁNIK, J. (2005). Možnosti výskumu kvantity pomocou existujúcich rečových databáz, [in:] Kvantita v spisovnej slovenčine a v slovenských nárečiach, Bratislava: VEDA. ISBN 8022408581.

Ferenćíková, A. (2005). Výskum kvantity v slovenských nárečiach, [in:] Kvantita v spisovnej slovenčine a v slovenských nárečiach, Bratislava: VEDA. ISBN 8022408581.

Findra, J. (1998). Jazyk, reč, človek, Bratislava: Vydavatel'stvo Q 111. ISBN 808540169X.

Findra, J. (2005). Kvantita: Spisovný jazyk verzus nárečia, [in:] Kvantita v spisovnej slovenčine a v slovenských nárečiach, Bratislava: VEDA. ISBN 8022408581.

Horňáková, K. a kol. (2005). Kniha o detskej reči, Bratislava: Slniečko. ISBN 8096907433.

Kačala, J. (1998). Spisovná slovenčina v 20. storočí, Bratislava: VEDA. ISBN 8022404977.

Kačala, J. (2005). Regulácia kvantity v rámci slova a tvaru, [in:] Kvantita v spisovnej slovenčine a v slovenských nárečiach, Bratislava: VEDA. ISBN 8022408581.

Králik, L. (2005). Historicko-etymologické poznámky k dištinktívnej funkcii kvantity $v$ súčasnej spisovnej slovenčine, [in:] Kvantita v spisovnej slovenčine a v slovenských nárečiach, Bratislava: VEDA. ISBN 8022408581.

Král, Á. (1983). Pravidlá slovenskej výslovnosti, Bratislava: SPN. ISBN 8008003057.

Král, A., Rýzková, A. (1989). Základy jazykovej kultúry, Bratislava: SPN. ISBN 8008002808.

Krčméry, Š. (1932). Melódia vety a prízvuk v slovenčine, [in:] Príloha Slovenských pohladov, roč. XLVIII, č. 7-8. 
Kvasnička, L. (1995). Abeceda nášho deda, Bratislava: Mladé letá. ISBN 8006006202.

Majtán, M. (2005). Takzvaná posunutá dľžka v južnostredoslovenských nárečiach, [in:] Kvantita v spisovnej slovenčine a v slovenských nárečiach, Bratislava: VEDA. ISBN 8022408581.

Mislovičová, S. (2005). Problémy kvantity v jazykovej praxi, [in:] Kvantita v spisovnej slovenčine a v slovenských nárečiach, Bratislava: VEDA. ISBN 8022408581.

Mistrík, J. (1999). Jazyk a reč, Bratislava: Mladé letá. ISBN 8006009244.

Navrátil, L. (2005). Uplatňovanie kvantity v hovorených prejavoch, [in:] Kvantita v spisovnej slovenčine a v slovenských nárečiach, Bratislava: VEDA. ISBN 8022408581.

Ondrejovič, S. (2005). Sociolingvistické poznámky k rytmickému kráteniu, [in:] Kvantita v spisovnej slovenčine a v slovenských nárečiach, Bratislava: VEDA. ISBN 8022408581.

Pauliny, E. (1979). Slovenská fonológia, Bratislava: Slovenské pedagogické nakladatel'stvo.

Piskurová, M. (2009). Zábavné úlohy pre prváčikov, Bratislava: Svojtka. ISBN 9788081071683.

Považaj, M. (2005). Uplatňovanie pravidla o rytmickom krátení a niektorých kvantitatívnych alternácií, [in:] Kvantita v spisovnej slovenčine a v slovenských nárečiach, Bratislava: VEDA. ISBN 8022408581.

Sabol, J. (2005). Historicko-synchronické morfologické a derivačné signály kvantity v slovenčine, [in:] Kvantita v spisovnej slovenčine a v slovenských nárečiach, Bratislava: VEDA. ISBN 8022408581.

Štúr, L. (1986). Dielo I, Bratislava: Tatran.

Šupšáková, B. (1998). Písmo a písanie, Bratislava: Univerzita Komenského v Bratislave. ISBN 8022312932.

Záborská, A. (2009). Technika reči 2, Banská Bystrica: Fakulta múzických umení. ISBN 9788089078547. 
